\title{
THE HEALTH AND SAFETY AT WORK ACT 2015: THE MYTH OF INCREASED DETERRENCE
}

\author{
Nadia Dabee*
}

\begin{abstract}
An assumption frequently made about the Health and Safety at Work Act 2015 is that the imposition of more responsibility on businesses and officers and higher criminal penalties will increase the deterrence of workplace accidents. This article argues that the anticipated increase in deterrence is a myth. In the new Act the definitions of duty-holders and their duties are broad and flexible. In theory, in the face of this broadness and flexibility, businesses who are risk-averse will over-comply with safety regulations to ensure they do not face a penalty. The new law appears to increase penalties and impose higher obligations on a greater number of duty-holders. However, in reality, the standard of care on employers remains unchanged, as do the enforcement mechanisms. Thus, in practice, the incentives to under-comply are higher than the incentives to over-comply and deterrence is unlikely to increase.
\end{abstract}

\section{INTRODUCTION}

This article argues that the deterrence of workplace accidents will not increase significantly under the Health and Safety at Work Act 2015 (HASWA), compared with deterrence under the Health and Safety in Employment Act 1992 (HASEA).

This article first gives a brief explanation of the deterrence theory, and explains that the rationale for imposing criminal liability on duty-holders is to deter workplace accidents. The article then seeks to clarify the understanding of the definitions of duty-holders under the HASWA by making reference to Australian jurisprudence. ${ }^{1}$

* Professional Teaching Fellow and PhD Candidate, Commercial Law Department, Business School, University of Auckland. I would like to thank my PhD supervisors, Associate Professors Chris Noonan and Gehan Gunasekara for their invaluable feedback.

1 Australian case law is an appropriate reference point to understand the New Zealand legislation as the Health and Safety at Work Act 2015 [HASWA] is based on the Workplace Health and Safety Act 2011 (Cth). 
Next, based on a review of the equivalent Australian legislation and court precedents, the article shows that, in some situations, duties are not precisely defined in the HASWA. Uncertainty in legal standards may cause some risk-averse businesses to over-comply with safety regulation, which should increase deterrence. ${ }^{2}$

However, there are three main reasons why deterrence will not increase under the HASWA. First, the HASWA does not impose, in practice, higher legal standards of care than the HASEA. There is thus no added incentive for businesses to increase their compliance efforts. Secondly, it is unlikely that the costs of punishment for non-compliance will ever exceed the cost of compliance. An examination of the sentencing of offenders by the courts bears this out. Thirdly, and most importantly, the regulator - WorkSafe - does not have enough resources to effectively identify, investigate and prosecute significantly high numbers of potential breaches. ${ }^{3}$ The risk of a breach being discovered will be discounted by duty-holders thus reducing the incentives to comply. ${ }^{4}$

Deterrence may increase slightly in industries with a high risk of death or serious injury as WorkSafe is focussing enforcement efforts on these industries, and a fine following a serious accident is likely to be severe. But deterrence will probably not increase significantly overall, across all industries.

The HASWA gives Health and Safety $(H \& S)$ representatives significant enforcement powers, which would ${ }^{5}$ at first glance, increase deterrence. However, having a H\&S representative is only compulsory in workplaces with 20 or more workers and if the person conducting a business or undertaking $(\mathrm{PCBU})^{6}$ is in a "high-risk sector or industry". ${ }^{7}$ Smaller businesses, which tend to have

2 See John E Calfee and Richard Craswell "Some Effects of Uncertainty on Compliance with Legal Standards" (1984) 70 Va L Rev 965.

3 Kevin Purse and Jillian Dorrian "Deterrence and Enforcement of Occupational Health and Safety Law" (2011) 27 International Journal of Comparative Labour Law and Industrial Relations 23. Enforcement has been identified as the most important factor for deterrence.

4 Duty-holders are persons who have obligations under the HASWA. PCBUs, officers and employees are the main duty-holders in the new Act.

5 HASWA, above n 1, s 16. An H\&S representative is a worker who has been elected by other workers to represent the interests of the workers.

6 Section 17. A PCBU "means a person conducting a business or undertaking whether alone or with others" and "whether or not ... conducted for profit or gain".

7 HASWA, above n $1, \mathrm{~s} 62$ 
worse safety outcomes, will not benefit from having $H \& S$ representatives who can use their ability to enforce the legislation as a deterrent measure. ${ }^{8}$

The liability of officers under the HASWA is discussed in a separate section. ${ }^{9}$ Whereas directors were liable as accessories to the company under the HASEA, the HASWA now imposes separate "due diligence" duties on directors personally. Duties are also imposed on officers of all types of organisations.

Even though there are now more duty-holders who fall within the definition of officers, and the duty requires officers to take positive steps to ensure their organisation complies with safety regulation, deterrence is also unlikely to increase significantly for officers. The risk of punishment remains small because of the low probability of breaches being detected and the low probability of a successful prosecution.

The article concludes by arguing that deterrence can only be increased by adopting draconian measures which are not feasible in practice. A further legislative initiative may be required to decrease the rate of workplace accidents in New Zealand.

\section{THEORETICAL BACKGROUND}

\section{A The Deterrence Theory}

There is an underlying assumption that deterrence should be at the core of occupational health and safety (OHS) legislation. ${ }^{10}$ The deterrence theory states that, if the costs of breaching a rule are higher than the costs of complying with the rule, then the duty-holder, seeking to minimise their costs, will comply with the rule. ${ }^{11}$ The deterrence theory presupposes that duty-holders are "rational utility maximisers": duty-holders will act rationally to maximise their gains or minimise their

8 See for example David E Cantor and others "Technology, Firm Size, and Safety: Theory and Empirical Evidence from the US Motor-carrier Industry" (2016) 55 Transportation Journal 149. There is a positive correlation between firm size and safety outcomes.

9 HASWA, above $\mathrm{n} 1, \mathrm{~s} 18$. An officer of a PCBU is defined as inter alia "any person occupying the position of a director of the company by whatever name called", a partner in a partnership, a general partner in a limited partnership, a person occupying a position similar to that of a director, or a person that has "significant influence over the management" of the PCBU.

10 Cantor, above $\mathrm{n} 8$.

11 David M Kennedy Deterrence and Crime Prevention: Reconsidering the Prospect of Sanction (Routledge, New York, 2009) at 1. See also Steve Tombs and David Whyte "The Myths and Realities of Deterrence in Workplace Safety Regulation" (2013) 53 Brit J Criminol 746 at 750. See generally Cesare Beccaria Of Crimes and Punishments (Oxford University Press, London, 1964); and JH Burns and HLA Hart Bentham: an Introduction to the Principals of Morals and Legislation (Methuen, London, 1982) at 74. 
losses. ${ }^{12}$ For the deterrence theory to work as predicted, duty-holders must be able behave rationally at all times and must have access to the right information.

However duty-holders may not be able behave rationally in practice. ${ }^{13}$ They may not have all the available information, or may be unable to fully understand the information they do have due to cognitive limitations - a phenomenon known as "bounded rationality". ${ }^{14}$ For example, a company director may not be able to fully understand, or even be aware of, their responsibilities under the HASWA and may assume they are complying, when they are not.

Duty-holders may not be able to accurately predict the legal consequences of their actions if they break the law. If they wrongly estimate the type of punishment they will receive, or the risk of being caught for a breach, they cannot accurately estimate the costs and benefits of breaking a rule. ${ }^{15}$ As this article will show, the risk of being caught for a breach, and the risk of receiving a severe punishment are low, except for very serious breaches. In general, duty-holders will tend to exaggerate the likelihood of not being caught, and under-comply. ${ }^{16}$

\section{$B$ The Deterrence of Companies}

Companies are the biggest employers in New Zealand. ${ }^{17}$ As employers, companies have a duty of care under the HASWA, so considering the deterrence of companies is important. The HASWA changes some of the mechanisms for corporate deterrence.

The identification doctrine will still apply to make the company liable. ${ }^{18}$ For example, when a floor manager does not do all that is reasonably practicable to ensure the safety of the workers on a

12 Kennedy, above n 11, at 16-17.

13 See generally Christine Jolls, Cass R Sunstein and Richard Thaler "A Behavioural Approach to Law and Economics"(1998) 50 Stan L Rev 1471; and Richard A Posner "Rational Choice, Behavioural Economics, and the Law" (1998) 50 Stan L Rev 1551. Jolls, Sunstein, Thaler and Posner also talk about "bounded willpower" and "bounded self-interest". See also Paul H Robinson and John M Darley "The Role of Deterrence in the Formulation of Criminal Law Rules: At its Worst when Doing its Best" (2003) 91 Ga L Rev 949 at 949 and 954.

14 Jolls, Sustein and Thaler, above n 13, at 1476; and Posner, above n 13, at 1555.

15 Kennedy, above n 11, at 16-17.

16 Paul Gordon and Alan Woodfield "Ex Ante Liability Rules in New Zealand's Health and Safety in Employment Act: A Law and Economics Analysis" (2007) 41 New Zealand Economic Papers 91.

17 As a rough indicator, 91 per cent of newly registered businesses in 2014-2015 were limited liability companies. "Statistics" (11 May 2016) New Zealand Companies Office <www.business.govt.nz >.

18 See generally Meridian Global Funds Management Asia Ltd v Securities Commission [1995] 3 NZLR 7 (PC) at 16 per Lord Hoffman. 
factory floor, the manager is acting as the company. ${ }^{19}$ It is the company who gets punished for failing to do all that is reasonably practicable to ensure the safety of the workers. Punishing the company should then, in theory, get the individuals within the company to react to the threat of a fine and ensure that the company meets its regulatory obligations. ${ }^{20}$ Brent Fisse and John Braithwaite argue that imposing liability on corporations does not always ensure that individuals within the company react by complying with regulation when there are no legal mechanisms to ensure steps are taken by the company to hold individuals within it accountable. ${ }^{21} \mathrm{~A}$ lack of legal rules to ensure that companies change the way they operate after an accident also means that the company can go on to commit the same breach, which means there is no deterrence. ${ }^{22}$

The HASEA tried to mitigate the lack of accountability by making directors liable as accessories to the company's breach when they participated in, or knew about the breach. ${ }^{23}$ Only company directors who were actively involved in the day-to-day running of the company have been punished. ${ }^{24}$ The HASWA tries to overcome the problem of lack of accountability in a different way. The HASWA imposes personal liability on officers of businesses to exercise due diligence to ensure the organisation complies with its obligations. ${ }^{25}$ The officer has a positive duty to act, and will be punished for failing to exercise due diligence.

This article will demonstrate that, even by making officers personally liable, deterrence is unlikely to increase significantly. The reason that deterrence will not increase is the uncertainty around enforcement of the new due diligence duties.

19 HASWA, above n 1, s 36. See Bilta (UK) Ltd (in liq) v Nazir (No 2) [2015] UKSC 23, [2016] AC 1 at [208] per Lord Neuberger: "attribution of the conduct of an agent so as to create liability on the part of the company depends very much on the context".

20 Brent Fisse and John Braithwaite Corporations, Crime and Accountability (Cambridge University Press, United Kingdom, 1993) at 1.

21 At 1.

22 At 1.

23 Health and Safety in Employment Act 1992 [HASEA], s 56.

24 See for example $R$ v Burr [2015] NZHC 2207.

25 The rationale for imposing due diligence duties on officers is also to improve workplace safety culture. See Robin Stewart-Crompton, Stephanie Mayman and Barry Sherrif National Review into Model Occupational Health and Safety Law: First Report (Australian Government, October 2008) [First Report] at [8.1]-[8.5]. 


\section{THE RATIONALE FOR IMPOSING CRIMINAL LIABILITY ON DUTY-HOLDERS}

Criminalising an act discourages most people from committing that act. ${ }^{26}$ For example, if it is a criminal offence to endanger workers' lives, all things being equal, an employer is more likely to take care not to endanger workers' lives than if the employer's liability was only civil. Thus, criminal liability was favoured over civil liability by the Australian National Review into health and safety legislation. ${ }^{27}$ Despite the procedural hurdles in securing criminal convictions, criminal liability was preferred as the threat of criminal sanctions was seen as increasing deterrence. ${ }^{28}$

The assumption that criminalising an act can increase deterrence does not always hold true, especially when businesses tend to see paying fines as an operational cost, rather than a criminal penalty. ${ }^{29}$

\section{DUTY-HOLDERS UNDER THE HASWA AND THEIR CORRESPONDING DUTIES}

\section{A PCBUs and the Changing Nature of Work}

The HASWA introduces the concept of a "person conducting a business or undertaking" (PCBU). The term "PCBU" replaces the term "employer" in the HASEA. An employer was someone who "employs any other person to do any work for hire or reward". ${ }^{30}$ The term was too restricted in scope as it did not cover all possible workplace arrangements. ${ }^{31}$

The modern workplace is evolving. ${ }^{32} \mathrm{New}$ technologies connecting workers to the workplace and businesses remaining open 24/7 require a flexible labour force. Workers can now be permanent, temporary or shift workers, on hire from employment agencies, volunteers or interns. Immigration, ageing populations and the fact that more women are engaged in the workforce are also changing the traditional model of labour under which one could expect a steady, life-long, nine-to-five job.

26 Robinson and Darley, above n 13, at 957.

27 First Report, above n 25, at [10.14]-[10.15].

28 First Report, above n 25, at Recommendation 50.

29 Ron McCallum, Toni Schofield and Belinda Reeve "The Role of the Judiciary in Occupational Health and Safety Prosecution: Institutional Processes and the Production of Deterrence" (2012) 54 Journal of Industrial Relations 688 at 698.

30 HASEA, above n 23, s 2 .

31 First Report, above n 25, at [6.53].

32 See generally Ali Dastmalchian and Paul Blyton "Workplace Flexibility and the Changing Nature of Work: An Introduction" (2001) 18 Canadian Journal of Administrative Science 1. 
To cover the myriad of new work arrangements, the HASWA has a broad and flexible definition of a PCBU. ${ }^{33}$ Section 17 defines a PCBU as a person conducting a business or undertaking, alone or with others, and whether or not for profit or gain. But the terms "person", "conducting" and "business or undertaking" are not defined.

Section 29 of the Interpretation Act 1999 defines the term "person" as including a "corporation sole, a body corporate, and an unincorporated body". Companies, partnerships and sole traders can be PCBUs. ${ }^{34}$ The term "conducting" implies a degree of control over the work being done, ${ }^{35}$ over the workers, ${ }^{36}$ and over the workplace. ${ }^{37}$

A "business" is a trade activity, a profession or the "carrying out of work as a whole". ${ }^{38}$ In s 2 of the Commerce Act 1986 and in s 2 of the Fair Trading Act 1986, the term "business" is defined as "any undertaking that is carried on for gain or reward" in the course of supplying goods and services or, "while acquiring or disposing of any interest in land".

The term "undertaking" is more difficult to define. The Court of Appeal of England and Wales explained the term to mean an "enterprise or business". ${ }^{39}$ In the Australian case Victorian WorkCover Authority v Horsham Rural City Council, Hansen J said: ${ }^{40}$

The word must take its meaning from the context in which it is used. In my view it means the business

or enterprise of the employer ... The circumstances must be as infinite as they may be variable.

Certain categories of persons are considered not to be conducting businesses or undertakings, that is, they are not PCBUs: workers, officers, volunteer associations, householders in most situations, statutory officers and any person expressly stated as not being a PCBU by law. ${ }^{41}$

Volunteer associations refer to groups of volunteers working together for one or more community purposes, for example, church organisations, hospices and the Red Cross. Volunteer

33 HASWA, above $\mathrm{n} 1, \mathrm{~s} 13$.

34 First Report, above n 25, at [6.51].

35 Robin Stewart-Crompton, Stephanie Mayman and Barry Sherrif National Review into Model Occupational Health and Safety Law: Second Report (Australian Government, January 2009) [Second Report] at [23.19].

36 At Recommendation 83

37 HASWA, above n 1, s 37.

38 Second Report, above n 35, at [23.13].

39 R v Associated Octel Co Ltd [1994] 4 All ER 1051 (Crim App) at 1061.The term is clearly intended to cover organisations that are not-for-profit: HASWA, s 17(1)(a).

40 Victorian WorkCover Authority v Horsham Rural City Council [2008] VSC 404 at [47].

41 HASWA, above n 1, s 17(1). 
associations are not PCBUs so as to not discourage volunteering by imposing heavy burdens on volunteer organisations. ${ }^{42}$ However, if a volunteer organisation employs another volunteer or an employee to carry out work, then it is a PCBU, ${ }^{43}$ for example, a volunteer organisation that carries out funding-raising activities, like running a shop. School trustees who employ people would also have duties under the HASWA.

Householders are generally not PCBUs but can become a PCBU in certain situations. For instance, a householder who has a party or a garage sale is not a PCBU. Householders who engage others for residential work, such as domestic chores, are also not PCBUs. If there is an employeremployee relationship between the householder and a third party, for example the householder and a nanny, then the householder is a PCBU.

A statutory officer performs duties in an official position established by legislation. ${ }^{44}$ Officers appointed to government departments, such as chief executives in the Ministry of Health, or appointed to local councils will not have a primary duty of care. But they may still owe a duty of "due diligence", for example, if they are an officer of the hospital. ${ }^{45}$ An elected member sitting on a regional council does not owe any duties of due diligence, ${ }^{46}$ unless they are also acting as an officer of the council. ${ }^{47}$

\section{B Confusion Reigns}

Submissions to the Transport and Industrial Relations Committee on the Health and Safety at Work Reform Bill show that the business community is in a state of confusion over the definition of a PCBU. For instance, the Business Leaders' Group has said that the term "PCBU" is "confusing and creates uncertainty". ${ }^{48}$ The Otago Southland Employers Association said the term was "the most confusing issue to come out of our recent consultation". 49

42 First Report, above n 25, at [6.10].

43 HASWA, above n 1, s 17(2).

44 Crimes Act 1961, ss 73-98F.

45 The Australian Review into the model OHS law recommended that directors and senior managers of the Crown be specifically included in the definition of "officer": Second Report, above n 35, at [23.147]. The HASWA does not specifically refer to directors and senior managers of the Crown, but the Act does not specifically exclude them either. See Part VI below for a definition of "officer".

46 HASWA, above n 1, s 52(2).

47 Health and Safety Reform Bill 2015 (192-2) (select committee report) at 8.

48 Business Leaders' Health and Safety Forum "Submission to the Transport and Industrial Relations Committee Health and Safety Reform Bill" at 2.

49 Otago Southland Employers Association "Submission to the Transport and Industrial Relations Committee Health and Safety Reform Bill: Strategic Review of the Workplace Health \& Safety System" at [5]. 
The fear may be unwarranted. Most employers (and officers) will know whether they owe a duty under the HASWA. In reality, uncertainty will exist in only a few situations. For example, would a farmer who gets his 12-year old and 10-year old to help milk the cows be a PCBU? The uncertainty of definitions at the margins may mean that a few duty-holders might not know they are duty-holders and thus might fail to comply with the HASWA, meaning they cannot be deterred at all.

\section{The Duties of PCBUs under the HASWA}

PCBU's owe a "primary duty of care" to workers and other persons. The term "primary duty of care" signifies the duty of care owed by those who can "direct or influence the way in which work is done"; that is, PCBUs. PCBUs owe a primary duty of care to ensure "as far as is reasonably practicable, the health and safety" of workers and of other persons who may be affected by the activities of the PCBU. ${ }^{50}$

The term "primary" is used to demonstrate the primacy or importance of the duty. ${ }^{51}$ The primary duties of care in the HASWA "establish the overarching [occupational health and safety] responsibilities of key parties involved in the conduct of a business or undertaking". ${ }^{52}$ The use of the word "primary" also connotes that the PCBU is being made directly, not vicariously, liable for the actions of its agents.

Under the HASEA, employers had to "take all practicable steps to ensure the safety of employees while at work". ${ }^{53}$ An employee was simply someone who was "employed by an employer to do any work (other than residential work) for hire or reward under a contract of service". ${ }^{54}$ Under the HASWA, the PCBU must ensure the health and safety of workers "so far as is reasonably practicable". ${ }^{55}$ The term "worker" is defined in relation to a PCBU. ${ }^{56}$ The definition is

50 HASWA, above n 1, s 36(1)-(2).

51 Barry Sherriff and Michael Tooma Understanding the Model Work Health and Safety Act (CCH Australia, Australia, 2010) at 17

52 First Report, above n 25, at [6.1].

53 HASEA, above n 23, s 6.

54 Section 2.

55 HASWA, above n 1, s 36

56 Section 19. 
broad and is meant to include volunteers, contractors, subcontractors and for-hire workers, ${ }^{57}$ an apprentice, a person gaining work experience and a person in a work trial. ${ }^{58}$

\section{Qualification of the Primary Duty of Care}

The primary duty in the HASWA is subject to the "reasonably practicable" test. The PCBU must take into account and weigh the following factors to ensure health and safety: ${ }^{59}$

(a) the likelihood of the hazard or the risk concerned occurring; and

(b) the degree of harm that might result from the hazard or risk; and

(c) what the person concerned knows, or ought reasonably to know, about-

(i) the hazard or risk; and

(ii) ways of eliminating or minimising the risk; and

(d) the availability and suitability of ways to eliminate or minimise the risk; and

(e) after assessing the extent of the risk and the available ways of eliminating or minimising the risk, the cost associated with available ways of eliminating or minimising the risk, including whether the cost is grossly disproportionate to the risk.

The "reasonably practicable" test seeks to limit the cost and effort of taking precautions in avoiding an accident and the resulting harm. While the HASWA says that the factors should be "weighed", the term "grossly disproportionate" suggests a test that requires more than just a simple cost-benefit analysis. For example, the PCBU has to take safety measures even if doing so could slow production, but not if it would make production impossible.

\section{E The Reasonably Practicable Test in the HASWA Contrasted with the All Practicable Steps Test in the HASEA}

Under the previous law, the duties of employers were subject to the "all practicable steps" test. ${ }^{60}$ The employer would have had to consider the nature and severity of the harm, the current state of knowledge about the likelihood of the harm and the harm itself, and the means available to prevent the harm. An employer could also consider the cost and availability of the protective means when deciding what practicable steps to take.

57 "For-hire workers" are workers sent to work for the PCBU by an employment agency.

58 Second Report, above n 35, at [23.249]-[23.261]. The term "work trial" is not defined.

59 HASWA, above n 1, s 22.

60 HASEA, above n 23, s 2 A. 
Taking all practicable steps under the HASEA did not require the duty-holder to do all that was "physically possible". 61 The New Zealand Court of Appeal in Attorney-General v Gilbert approved the "balancing" approach. ${ }^{62}$ The Court explained that the "obligation requires reasonable steps which are proportionate to known and avoidable risks". 63

Take the simple task of choosing the right protective personal equipment (PPE) for a particular task. ${ }^{64}$ The employer needs to foresee the risks associated with a task, for example, the possibility of burns from steam or from molten metal in a foundry. ${ }^{65}$ The employer must also know of the latest technology and materials available to protect against burns. When deciding which type of material to use, the employer needs to look at the benefits and disadvantages of each material, like the protection level against molten metal or steam. The employer also needs to consider the physiological effects on the wearer, for example, the weight and breathability of the material. ${ }^{66}$ The availability and cost of the protective gear is also relevant in deciding which safety measures to take. ${ }^{67}$ The decision on what safety measures to adopt will often involve a "compromise between competing interests". 68

The new duty under the HASWA says that the duty-holder must take the precaution unless the cost is grossly disproportionate to the risk. The purpose of the HASWA is to provide workers with "the highest level of protection against harm". ${ }^{69}$ This may suggest a higher standard of care than under the HASEA, which is what some of the submitters on the Bill believed. ${ }^{70}$

Australian case law may shed some light on how the reasonably practicable test could be interpreted under the HASWA. ${ }^{71}$ Queensland, New South Wales, the Australian Capital Territory,

61 Edwards v National Coal Board [1949] 1 KB 704 (CA) at 712 per Asquith LJ.

62 Attorney-General v Gilbert [2002] 2 NZLR 342 (CA) at [83].

63 At [83].

64 See for example Buchanans Foundry Ltd v Department of Labour [1996] 3 NZLR 112 (HC).

65 At 336.

66 At 336.

67 At $338-339$.

68 At $336-337$

69 HASWA, above n 1, s 3.

70 A submission to the Transport and Industrial Relations Committee on the Health and Safety in Employment Bill said that the HASWA would impose a higher standard of care than under the HASEA: Simpson Grierson "Submission to the Transport and Industrial Relations Committee Health and Safety Reform Bill" at 4 .

71 Dinko Tuna Farmers Pty Ltd v Markos [2007] SASC 166, (2007) 98 SASR 96 at [44]. 
the Northern Territory, South Australia, Tasmania and the Commonwealth of Australia have adopted the Model Act for Workplace Health and Safety. The definition of reasonably practicable in these six states and in the Commonwealth legislation is similar to the definition of reasonably practicable in the HASWA. ${ }^{72}$

The Fairwork Commission has applied and explained the reasonably practicable test. ${ }^{73}$ The Commission balanced the cost of repairing a column at the entrance of a building against the risk of serious harm or death if the column was hit by a delivery truck. ${ }^{74}$ The conclusion was that the cost of fixing the column was low compared to the high risk of a serious accident occurring.

The Federal Court of Australia also carried out a balancing exercise and considered the practicability of preventing the harm (putting a guard over boat propellers) and the possible harm (serious injury to anyone swimming near the boat), and decided that the employer had not done all that was reasonably practicable to protect employees. ${ }^{75}$

There are a couple of Australian cases that show that the courts there seem to have adopted a proportionality test, rather than a gross disproportionality test. The new test, as interpreted and applied by the Australian courts, does not differ dramatically from the old test.

The New Zealand courts may decide to veer away from the Australian courts' interpretation. They may conclude that the term "grossly disproportionate", when balancing risks in relation to costs, means that a higher standard of care is required from PCBUs.

\section{F Codes of Practice}

A code of practice is an approved method of carrying out a particular job or task in a manner that has been proven to reduce the risk of accident. ${ }^{76}$ Codes of practice were also used under the HASEA. ${ }^{77}$ WorkSafe, New Zealand's OHS regulator, is responsible for developing codes of

72 Workplace Health and Safety Act 2011 (Qld), s 18; Workplace Health and Safety Act 2011 (NSW), s 18; Workplace Health and Safety (National Uniform Legislation) Act 2011 (NT), s 18; Workplace Health and Safety Act 2012 (SA) s 18; Workplace Health and Safety Act 2012 (Tas) s 18; and Work Health and Safety Act 2011 (Cth), s 18 .

73 The Australian Postal Corporation v Comcare [2014] FWC 3228.

74 At [57]-[58].

75 Comcare v Commonwealth of Australia [2012] FCA 1419 at [64]-[66]. A young trainee suffered severe injuries after falling into the water near an unguarded propeller. Other trainees had suffered propeller injuries before him, but the previous injuries were not as severe.

76 HASWA, above n 1, s 222; and WorkSafe New Zealand Act 2013, s 10(e).

77 HASEA, above n 23, s $20 B$. 
practice. ${ }^{78}$ WorkSafe has an obligation to consult with employers, unions and "other persons affected" when developing codes. ${ }^{79}$ Once approved by the Minister, the code becomes an approved code of practice (ACOP). ACOPs are tailored to suit the particular industry they are used in and can be changed quickly, compared with primary legislation, in response to changes within an industry.

Following an ACOP is a way for a PCBU to show they have discharged their duties under the HASWA; that is, to show they have done all that is reasonably practicable. ${ }^{80}$ It is not compulsory for a PCBU to follow an ACOP. A PCBU can also show they have taken all practicable steps by providing evidence that they have a system of work with safety standards that are equivalent or better than the safety standards in the ACOP. ${ }^{81}$

Unfortunately, relying on a code of practice is not always straightforward. While ACOPs are available free of charge on the internet, ${ }^{82}$ and hard copies can be purchased for a reasonable charge, ${ }^{83}$ ACOPs do not exist for every workplace situation in New Zealand. The PCBU may then have to spend time and money obtaining a code of practice from a professional body. For example, there are no ACOPs on food packaging in New Zealand. A PCBU would have to purchase a code of practice from an international body such as the International Organisation for Standardisation (ISO). Applying the ISO standard could be a way of doing all that is reasonably practicable to ensure safety.

Even if codes of practice are readily available, there may be hurdles in implementing them. Codes that are not drafted carefully could be too broad to be usefully implemented. ${ }^{84}$ The code may not deal with the specifics of the business and may not be easily adaptable to a particular situation. They may be poorly written and not easily understood, ${ }^{85}$ or even be out of date. Also, a PCBU might lack the expertise to be able to implement it. ${ }^{86}$

78 WorkSafe New Zealand Act 2013, s 10(e).

79 HASWA, above n 1, s 222.

80 Section 233(2) and 233(3)(b).

81 Section 233(4).

82 Section 231(1).

83 Section 231(2).

84 Elizabeth Bluff and Neil Gunningham A Review of Key Characteristics that Determine the Efficacy of OHS Instruments (Australian Safety and Compensation Council, July 2008) at [30].

85 At [342].

86 At [350] and [351]. 
The new law does not propose solutions to resolve old uncertainties in implementing ACOPs and codes of practice.

\section{G The Primary Duty of Care to Other Persons}

Under the HASEA, employers had to "take all practicable steps to ensure that no action or inaction of any employee while at work harms any other person", such as a member of the public who enters a construction site. ${ }^{87}$

Under the HASWA, PCBUs must ensure: 88

... so far as is reasonably practicable, that the health and safety of other persons is not put at risk from

work carried out as part of the conduct of the business or undertaking.

Other persons could include people such as visitors or clients using the facilities. ${ }^{89}$

It is not just the actions or inaction of employees that the PCBU has to manage, ${ }^{90}$ but the whole of its undertaking should be safe to other persons. For example, an employee could cause harm by accidentally spilling a toxic substance. The PCBU will have to manage the toxic spill at the place of work itself so that the toxic substance does not harm workers and visitors. If, however, there is a risk of the spill spreading to the road or sewage systems, then the PCBU will also have to take steps so far as is reasonably practicable, to prevent this occurring.

While the wording of the new law appears wider in scope, an employer would have had to do the same under the old law.

\section{H Other Duty-Holders and their Duties}

\section{Workers}

Workers can still influence the safety of the workplace, but do not have as much influence as a PCBU. ${ }^{91}$ Also, PCBUs stand to gain more economically from their undertaking than employees. Therefore, workers have less onerous duties than PCBUs. ${ }^{92}$

87 HASEA, above n 23, s 15.

88 HASWA, above n 1, s 36(2).

89 In Dean Allan Coggins v Sunmanor Pty Ltd Industrial Court of Queensland C/2009/60, 17 June 2010, a white-water kayaking business was held to have duties to its customers.

90 Cardrona Ski Resort Ltd v Department of Labour HC Invercargill CRI-2009-425-16, 11 September 2009.

91 The HASWA replaces the term "employee" with the term "worker". HASWA, above n 1, s 19 defines "worker" as including employees, contractors, subcontractors, employees of contractors or of subcontractors.

92 Sherriff and Tooma, above n 51, at 52. 
Under the HASEA, employees had to "take all practicable steps" to ensure their safety and those of "any other person". ${ }^{93}$ Employees had to follow instructions of the employer. Under the HASWA, a worker has to take "reasonable care" of his or her own health and safety and ensure that their acts or omissions do not affect the safety of other persons. ${ }^{94}$ Workers also need to "as far as they are reasonably able" comply with reasonable instructions given by the PCBU and reasonable workplace policies and procedures. ${ }^{95}$ The term "reasonable care" implies an objective standard, ${ }^{96}$ but not one as stringent as the duty to take "all practicable steps".

Even if the duty of care on employees is less onerous under the new law, the application of the new duties is not expected to differ dramatically from the application the old duties. For instance, in Department of Labour $v$ Adams, decided under the HASEA, Mr Adams, a crane operator and employee of Central Cranes Ltd, swivelled his crane so that his portal came into contact with overhead power lines. ${ }^{97} \mathrm{Mr}$ Brownlee, who was holding onto the portal with a cable, was electrocuted and killed when the portal hit the power lines. The defendant was convicted for not taking all practicable steps to prevent harm; ${ }^{98}$ it was standard procedure to look out for power cables before beginning work.

The outcome of the Adams case will almost certainly be the same under the HASWA. The defendant did not take reasonable care to prevent injury to Mr Brownlee by looking out for power cables and the defendant also failed to follow the standard safety procedure of looking out for cables.

\section{Other persons}

Visitors and other persons passing through a worksite may, by their actions or inactions affect the safety of workers and other persons. ${ }^{99}$ There is now a new duty on other persons at a workplace to "take reasonable care of his or her own safety", ${ }^{100}$ and to ensure "that his or her acts or omissions do not adversely affect the health and safety of other persons". ${ }^{101}$ There is also a duty to comply with instructions from the PCBU as far as those instructions allow the PCBU to comply with the

93 HASEA, above n 23, s 19.

94 HASWA, above n 1, s 45(a)-(b).

95 Section $45(\mathrm{c})-(\mathrm{d})$.

96 Sherriff and Tooma, above n 51, at 52.

97 Department of Labour v Adams DC Pukekohe CRN6057007360, 18 September 2003.

98 He was prosecuted for a breach of s 50 of the HASEA.

99 First Report, above n 25, at [9.22]-[9.23].

100 HASWA, above n 1, s 46(a).

101 Section 46(b). 
HASWA. ${ }^{102}$ Cases involving the prosecutions other persons are likely to be few as WorkSafe usually focuses prosecution efforts on employers and employees. ${ }^{103}$

\section{Principals}

Under s 18 of the HASEA, principals had to take all practicable steps to ensure that no contractor or subcontractors or their employees were harmed while doing work they were engaged to do. ${ }^{104}$ In Central Cranes Ltd v Department of Labour, decided under the HASEA, the Court held that the duty of the contractor towards its employees was "patently greater" than the duties of the principal as the former were the direct employers. The principal was not, however, exonerated from liability. ${ }^{105}$ Central Cranes, as the principal, still had to take all practicable steps to ensure the safety of the employees of Skytech, the subcontractor. ${ }^{106}$ The principal was held to have breached its duties to the employees of the subcontractors. Central Cranes could have taken more steps to ensure the safety of Skytech's employees, for example, by talking to Skytech to ensure that the employees were using the correct safety gear.

The guidelines issued for principals under the HASEA by the Ministry of Business, Innovation and Employment (MBIE) made it clear that principals cannot feign ignorance of safety matters affecting the employees of the contractor or subcontractor. ${ }^{107}$ It is clear that negotiation about safety processes must have occurred between principals and contractors. ${ }^{108}$

Two sections in the HASWA are relevant to understand the duties of principals. First, s 36(1)(b) states that a PCBU owes a primary duty of care to workers whose activities are "influenced or directed" by the PCBU. The work of the principal would influence employees of a contractor or subcontractor, so the principal has to do what is "reasonably practicable" to look after the safety of employees of contractors and of subcontractors. What is reasonably practicable for a PCBU depends

102 Section 41(c).

103 No prosecutions against other persons have been made thus far. The regulator also targets its education efforts towards employers and workers: see for example "Information and Guidance" (2016) WorkSafe New Zealand <www.worksafe.govt.nz>.

104 HASEA, above n 23, s 18.

105 Central Cranes Ltd v Department of Labour [1997] 3 NZLR 694 (CA) at 702.

106 At 702. The judgment states that if "there is a step which it would be practicable for [Central Cranes] to take ... that step is required to be taken irrespective of what steps might be required of the employer".

107 Ministry of Business, Innovation and Employment A Principal's Guide to Contracting to Meet the Health and Safety in Employment Act 1992 (May 2010) at 7-10.

108 At 20-51. 
on their ability to take steps to implement safety measures. ${ }^{109} \mathrm{~A}$ principal will be less able to direct the employees of the contractor than the contractor would.

Secondly, s 34 places duties on PCBUs with the same duty of care to consult, cooperate with and coordinate their activities with each other. For example, the principal, contractors and subcontractors all owe primary duties to workers on the same site, ${ }^{110}$ and now have a legal requirement to consult, cooperate and coordinate their activities. The potential fine is up to $\$ 20,000$ for an individual and $\$ 100,000$ for any other person who fails to comply. ${ }^{111}$

Previously the requirements to consult, cooperate and coordinate were part of the MBIE guidelines for principals. The threat of a fine under the new law may nudge a few more principals to discuss safety with contractors and subcontractors.

\section{Effect of uncertain legal standards}

Paul Gordon and Alan Woodfield argue that the legal standard of care, in the HASEA, about taking all practicable steps is uncertain. ${ }^{12}$ As shown above, the new legal standards do not differ dramatically from the old ones. While uncertain legal standards may increase deterrence in riskaverse businesses, uncertain legal standards in combination with low penalties mean that employers are likely to underestimate the level of care needed. ${ }^{113}$

To offset the tendency of employers to under-comply, Gordon and Woodfield argue that higher rates of inspection and higher penalties would be needed. ${ }^{114}$ Thus, they argue that legislation should allow for higher fines and the cost of the fine should also be greater than the cost of investing in measures that comply with the HASEA. ${ }^{115}$ But, as explained below, significantly higher fines and higher inspection rates remain unlikely under the new regime.

\section{New Offences and Increased Penalties}

Under s 49 of the HASEA, it was an offence for "a person" to knowingly take any action or fail to take an action, where the action was "reasonably likely to cause serious harm to any person". ${ }^{116}$

109 First Report, above n 25, at [6.84]

110 This will affect PCBUs who have duties under ss $37-43$ as well.

111 HASWA, above n 1, s 34(2).

112 Gordon and Woodfield, above n 16.

113 At 102

114 At 106

115 At 94-96. Such an increase in the fine amount would then require the court to hear expert evidence on the cost of the complying safety measures.

116 HASEA, above n 23, s 49(1)-(2). 
The action or inaction had to be "contrary to the provision [of the HASEA]", for example, failing to take all practicable steps to ensure the safety of employees under s 6. Fines of up to $\$ 500,000$ and/or two years' imprisonment were possible for a breach of s 49 .

Section 50 created a further offence for failing to meet the requirements of the HASEA. For example, it was an offence for an employer to fail to take all practicable steps to ensure the safety of employees under s 6 It would have also been an offence to fail to give the appropriate training and supervision to an employee as required by s 13 . A fine of up to $\$ 250,000$ was possible for a breach of $\mathrm{s} 50$ of the HASEA. ${ }^{117}$

The penalties under the HASWA are significantly higher than under the HASEA. The Independent Taskforce on Workplace Safety (the Taskforce) was clearly in favour of increasing fines to improve deterrence. ${ }^{118}$ They recommended an increase in fines that would be in line with the fines imposed in Australia. ${ }^{119}$ The Australian National Review on workplace safety said that high maximum fines would have the "salutary effect in raising commitment to good OHS", even though the application of the maximum penalties would be rare in practice. ${ }^{120}$

There are three offences under the new legislation, with significantly higher penalties. Firstly, there is the offence, under s 47 , of a duty-holder who recklessly engages in conduct that exposes someone to a risk of death or serious injury or serious illness. The conduct must still also be contrary to the Act. The Australian National Review into the OHS Model Act said this offence would apply to "the most serious breaches, where there was a high level of risk of serious harm and the duty holder was reckless or grossly negligent". ${ }^{121}$ Recklessness refers to the state of mind of the duty-holder and considers whether a reasonable person, in the shoes of the duty-holder, would have foreseen the risk of harm and gone on to take the risk. ${ }^{122}$ Apart from the level of punishment, this new section is similar to s 49 of the HASEA.

For an individual who is convicted of an offence under s 47 and who is not a PCBU or an officer of a PCBU, for example an employee, a fine of up to $\$ 300,000$ and/or a term of imprisonment not exceeding five years may be imposed. ${ }^{123}$ For an individual who is a PCBU or an officer of a PCBU,

117 Sections 49 and 50 .

118 Rob Jager and others The Report of the Independent Taskforce on Workplace Health and Safety: He Korowai Whakaruruhau (Ministry of Labour, April 2013) [Taskforce Report] at [326]-[328] and [391]

119 At [385]. See also Work Health and Safety Act 2011 (Cth), ss 31-33.

120 First Report, above n 25, at [12.22].

121 First Report, above n 25, at Recommendation 55.

122 See generally $R v$ Cunningham [1957] 2 QB 396 (CA).

123 HASWA, above n 1, s 47(3)(a). 
a fine of up to $\$ 600,000$ and/or up to five years' imprisonment is possible. ${ }^{124}$ For any other person, for example a company who is a PCBU, a fine of up to $\$ 3$ million may be imposed. ${ }^{125}$

Secondly, there are two strict liability offences under the HASWA. Section 48 makes it an offence to fail to comply with a duty in the HASWA thereby exposing an individual to a risk of death or serious injury. Section 48 would apply when there is a "high level of risk of serious harm but without recklessness or gross negligence". ${ }^{126}$ This offence did not exist under the HASEA. This specific offence did not exist under the HASEA. Under that Act, a breach of a duty that was not reckless but risked death or serious harm or illness could be punished by a fine of up to $\$ 250,000$. ${ }^{127}$ Under the new offence in the HASWA, the courts may impose higher fines for such breaches. For a breach of s 48 , fines of up to $\$ 150,000$ are possible for individuals who are not PCBUs or officers of PCBUs. ${ }^{128}$ Individuals who are PCBUs or officers of PCBUs may be fined up to $\$ 300,000 .{ }^{129}$ Other persons who are PCBUs may be fined of up to $\$ 1.5$ million. ${ }^{130}$

Section 49 makes it an offence to fail to comply with a duty in the HASWA. Section 49 applies when there are breaches of a duty without any of the aggravating factors in ss 47 and $48 .{ }^{131}$ Section 49 thus applies when there is a breach of duty that carries no "risk of death or serious injury or serious illness". This offence is similar to the offence under s 50 of the HASEA, apart from the level of the fines. For a breach of s 49, individuals who are not PCBU or who are not officers of PCBUs may be subject to a fine of up to $\$ 50,000 .{ }^{132}$ An individual who is PCBU or an officer of a PCBU may be subject to a fine of up to $\$ 500,000 .{ }^{133}$ And for other persons who are PCBUs, a fine of up to $\$ 500,000$ is possible. ${ }^{134}$

The next section will consider whether the new offences and the increased penalties will lead to increased deterrence when they are enforced in practice.

\author{
124 Section 47. \\ 125 Section 47(2)(c). \\ 126 First Report, above n 25, at Recommendation 55. \\ 127 HASEA, above n 23, s 50. \\ 128 HASWA, above n 1, s 47(2)(b). \\ 129 Section 48(2)(a). \\ 130 Section 48(2)(c).
}

131 First Report, above n 25, at Recommendation 55.

132 HASWA, above n 1, s 49(2)(a).

133 Section 49(2)(b).

134 Section 49(2)(c). 


\section{THE ENFORCEMENT OF THE HASWA}

\section{A The Approach of the Courts}

Increasing the maximum penalties will have no effect on deterrence unless the courts are willing to impose higher fines and jail sentences. There are some reasons to doubt substantially higher penalties will be imposed under the HAWSA.

\section{Tension with reparations}

Under the HASEA, courts had been awarding higher reparation amounts over high fines. ${ }^{135}$ Reparation amounts are sums paid directly to the victim, ${ }^{136}$ and can be insured against. High reparation amounts can also be used to offset the amount of the fine the defendant has to pay. ${ }^{137}$ Offsetting the fine amount usually happens when the defendant can only afford the reparation amount. ${ }^{138}$ Increasing reparation amounts does not increase deterrence since the cost of the reparation is not usually borne directly by the defendant, but by the insurance company. The cost of the premium can then become a fixed running cost to the business.

2 When pecuniosity is a factor: The de Spa decision and the Sentencing Act 2002

Courts must use the guidelines in the Sentencing Act 2002 when determining the level of fine to impose. Aggravating circumstances such as the vulnerability of the victim and mitigating circumstances such as the remorse shown by the offender are taken into account. ${ }^{139}$ Offers to make amends to the victim can also be taken into consideration by the court to reduce the amount of the fine. ${ }^{140}$ PCBUs who are companies cannot show remorse. The pecuniosity of a PCBU-company is the main factor that a court is likely to take into account during sentencing.

The decision of Department of Labour $v$ de Spa and Co Ltd directs that fines must be commensurate with the employer's pecuniosity. ${ }^{141}$ The degree of culpability, the harm that occurred,

135 See "Media Releases" WorkSafe New Zealand <www.worksafe.govt.nz〉.

136 Sentencing Act 2002, ss 11-14.

137 Section 14.

138 See Department of Labour v Hanham \& Philp Contractors Ltd (2008) 6 NZELR 79 (HC) at [64]-[71].

139 Sentencing Act 2002, s 9.

140 Section 10 .

141 Department of Labour $v$ de Spa \& Co Ltd [1994] 1 ERNZ 339 (HC) at 343-344. The court in Hanham also said that the starting point of the fine should depend on the defendant's level of "culpability", above n 138 at [54] and [61]-[62]. 
whether or not a guilty plea was entered, compensation made to the victim and the employer's safety record are further factors in determining the level of the fine. ${ }^{142}$

The most significant mitigating factor for fines is the financial means of the employer. ${ }^{143}$ The rationale for looking at the employer's financial means before imposing a fine is to keep the business afloat and preserve jobs. ${ }^{144}$ Higher fines will most probably be externalised (passed onto others) by the business. Goods may end up costing more, dividends on shares may drop, and, worst of all, employees may lose their jobs. The loss of jobs is what the courts may be trying to prevent by limiting fines.

If an employer knows they will only ever receive a fine that they can afford to pay, there may never be sufficient deterrence. The cost of investing in safety measures will not exceed the cost of the fine. The Taskforce recommended that businesses that harm workers should have to pay stiffer fines, even if the consequence was the business shutting down. ${ }^{145}$ The Taskforce was of the view that a significant number of businesses failed anyway due to a poor business model. Under such a model they could not afford good health and safety measures and should be shut down.

It seems unlikely, at this point in time, that courts will be willing to impose fines that will lead to businesses shutting down. Courts seem more willing to impose high reparation amounts. To avoid passing on costs of fines to the business, liability can pinned on individuals. Under the HASWA, officers of PCBUs can be fined higher amounts without making the business pay a fine it cannot afford. Officers, like businesses, cannot insure against the cost of a fine. ${ }^{146}$ However, as will be discussed in Part VI below, the problem of detecting breaches and securing convictions for an officer's breach of due diligence duties remains.

\section{$B$ Certainty of the Enforcement}

A survey of empirical data on the deterrence of workplace accidents revealed that certainty of enforcement is the most important factor for deterrence. ${ }^{147}$ Gordon and Woodfield revealed that

142 Department of Labour v de Spa \& Co Ltd, above n 141, at 343-344.

143 Alan Woodfield, Stephen Hickson and Andrea Menclova An Empirical Analysis of Changing Guidelines for Health and Safety in Employment Sentences in New Zealand (Working Paper No 14/2013 Department of Economics and Finance, University of Canterbury, Christchurch, 2013) at 3.

144 Department of Labour v de Spa \& Co Ltd, above n 141, at 343: "A fine at a particular level will obviously bear differently upon a small impecunious employer as opposed to a large financially strong employer."

145 Taskforce Report, above n 118, at [389].

146 Companies Act 1993, s 162.

147 Purse and Dorrian, above n 3. See also Calfee and Craswell, above n 2, at 981. 
inspection rates were below the level required for effective deterrence. ${ }^{148}$ The Taskforce also found that enforcement of regulation was ineffective as there were not enough inspections and the chances of being caught for non-compliance were very low. ${ }^{149}$ The Taskforce thus recommended an increase in capacity for enforcement and surveillance. ${ }^{150}$

The Government has responded by providing an additional $\$ 33$ million to increase the number of workplace inspectors. WorkSafe had 137 inspectors in 2013-2014, that is one inspector for every 3,561 workplaces, with a plan to increase the number of inspectors to 200 by $2016 .{ }^{151}$ That still means only one inspector for every 2,500 workplaces. To visit every single workplace just once a year, each inspector would have to inspect 6.8 workplaces every single day of the year.

It is difficult to say what the optimum rate of inspection should be. However, a study of food safety in restaurants suggests that the optimal rate of inspections should be three to four times a year for every business. ${ }^{152}$ Unfortunately, only 14,248 health and safety assessments were carried out by WorkSafe last year. In other words, out of a total of 487,875 businesses in New Zealand, only 2.9 per cent were inspected. ${ }^{153}$ There are not enough inspections being carried out to detect and punish even the majority of violations, save for the most severe and obvious ones.

A limited number of inspectors has meant that WorkSafe has had to prioritise the use of its inspectorate. One of the strategies WorkSafe adopted to maximise the use of its inspectors is to focus on high hazard industries. ${ }^{154}$ The Taskforce has suggested that activities which could lead to catastrophic disasters should be classified as high hazard industries and actively monitored. ${ }^{155}$ Focussing on a few businesses may increase specific deterrence in those industries. Unfortunately, overall, deterrence in most other sectors is unlikely to increase.

148 Gordon and Woodfield, above n 12, at 91 and 92.

149 Taskforce Report, above n 118, at [129].

150 At [148]

151 Worksafe New Zealand WorkSafe Annual Report 2013-2014 (2014) at 8.

152 K Bruce Newbold and others "Restaurant Inspections Frequency and Food Safety Compliance" (2008) 71 J Environ Health 56 at 59.

153 WorkSafe Annual Report 2013-2014, above at n 151, at 3.

154 At 3 .

155 Taskforce Report, above n 118, at [311]. 


\section{The decision to prosecute}

WorkSafe's prosecution policy follows the Solicitor General's guidelines for prosecuting. ${ }^{156}$ The evidential test and the public interest test must both be passed before WorkSafe will start a prosecution. Under the evidential test, if the quality of the evidence does not foretell a reasonable chance of a successful prosecution, then WorkSafe will not prosecute. ${ }^{157}$ If the evidential test is passed, WorkSafe must decide whether the prosecution is in the public interest. ${ }^{158}$ Other factors to consider are whether a death occurred, the seriousness of the offence, disregard for safety, repeated breaches and obstruction of inspectors among others. In Australia, such an approach was found to be time-consuming and frustrating for inspectors, with more time spent deciding whether to prosecute and dealing with complaints rather than taking action to investigate an accident. ${ }^{159}$

\section{Worker participation and representation}

Worker engagement and participation is crucial for good workplace safety. ${ }^{160}$ The HASWA gives H\&S representatives some significant powers which, in theory, should give more bargaining power to workers to negotiate better OHS conditions.

$\mathrm{H} \& \mathrm{~S}$ representatives have the power to issue improvement notices on a person they "believe ... is contravening, or is likely to contravene" one of the duties in the HASWA. ${ }^{161}$ The notice must include details of the contravention and how the contravention may be remedied. An individual who breaches a provisional notice may be subject to a fine of up to $\$ 50,000 .{ }^{162}$ The fine is up to $\$ 250,000$ for any other person. ${ }^{163}$ The fact that provisional notice must also be displayed in a "prominent place at or near the workplace" is an attempt to use a naming and shaming tactic to get PCBUs to comply. ${ }^{164}$ Failing to display the notice could result in a fine of up to $\$ 5,000$ for an

156 WorkSafe New Zealand Prosecution Policy (May 2016) at 9.

157 At [7.1].

158 At [7.2]

159 Toni Schofield, Belinda Reeve and Ron McCallum "Australian Workplace Health and Safety Regulatory Approaches to Prosecution: Hegemonising Compliance" (2014) 56 Journal of Industrial Relations 709 at 718 and 720 .

160 See generally Dov Zohar "Safety Climate in Industrial Organisations: Theoretical and Applied Implications" (1980) 65 Journal of Applied Psychology 96 at 97; and Beatriz Fernandez-Muniz, Jose Manuel MontesPeon and Camilo Jose Vazquez-Ordas "Safety Culture: Analysis of the Causal Relationships between its Key Dimensions" (2007) 38 Journal of Safety Research 627 at [2.2.3]

161 HASWA, above n 1, s 69

162 Section 78(4)(a).

163 Section 78(4)(b).

164 Section 76(1). 
individual and up to $\$ 25,000$ for other persons. ${ }^{165}$ The representative can also direct the cessation of unsafe work when they hold the reasonable belief that the work would expose a worker or other person to an OHS serious risk. The threat must be "immediate or imminent". 166

Under the HASWA, it is mandatory for PCBUs in high-risk sectors with 20 or more workers to have an H\&S representative. High-risk sectors include the mining, petroleum extraction and exploration, forestry and hunting, building construction, and heavy and civil engineering construction industries. ${ }^{167}$

However, less than one per cent of businesses in New Zealand which fall in the high-risk category have 20 or more employees. ${ }^{168}$ Moreover, large businesses in high-risk industries may already tend to have good OHS practices. ${ }^{169}$ Thus, the majority of businesses in New Zealand will not benefit from the increased deterrence that could come from H\&S representatives having enforcement powers.

\section{OFFICERS}

\section{A Duties of Directors under the HASEA}

When a company committed an offence under the HASEA, the "director, officer or agent" of the company could be made a party to the offence. ${ }^{170}$ To be liable, the director would have had to have "directed, authorised, assented to, acquiesced in, participated in, the failure of the company". ${ }^{171}$.

Under s 49 of the HASEA, a company was criminally liable if the company had knowingly taken an action that was likely to cause serious harm to any person, or had knowingly failed to take an action where such an action would cause serious harm to any person. To be liable, the director would have had to have knowledge of, or participated in, the company's failings.

165 Section 76(3).

166 Section 84 .

167 For a full list of "high-hazard industries" see Health and Safety at Work (Worker Engagement, Participation, and Representation) Regulations 2016, $\mathrm{r} 5$.

168 "New Zealand Business Demography Statistics 2015" Statistics New Zealand <www.stats.govt.nz>. There are 502,170 businesses in New Zealand.

169 See generally Ole Henning Sorensen, Peter Hasle and Elsa Bach "Working in Small Enterprises - Is there a Special Risk?" (2007) 45 Safety Science 1044. The authors' literature review reveals that larger organisation have significantly better safety systems than smaller organisations.

170 HASEA, above n 23, s 56.

171 Section 56. 
For example, in $R v$ Burr, Mr Burr, acting as an employee of Paul Burr Contracting Limited (Paul Burr Ltd), had knowingly failed to take all practicable steps to prevent serious injury to a coworker while operating a tree harvester. ${ }^{172}$ His actions were attributed to Paul Burr Ltd, and Paul Burr Ltd was liable as an employer under s 49. Mr Burr had participated in the company's failure by failing to ensure safety procedures were in place and negligently using the harvester. Because he was also a director, he was also liable under s $56 .{ }^{173}$

Under s 50 of the HASEA, the company was only liable if it had failed to comply with its statutory obligations. The directors of the company were only liable for a failure of the company to comply with s 50 of the HASEA if they had knowledge of the failure or had participated in it. ${ }^{174}$

An example is the case of McGall v Dominion Bookbinders Ltd. ${ }^{175}$ The company had failed to provide a safe workplace and an employee's child was injured. The child had been climbing a gate when the gate collapsed injuring the child. The company was liable for a breach of s 50 for failing to provide a safe workplace for any other person. ${ }^{176}$ The director was aware that the gate was defective, and had thus "participated" in the breach. ${ }^{177}$ The director was personally liable under s 56.

Under the HASWA, a director is no longer liable as an accessory to the company. The director now has a separate duty to exercise "due diligence" to ensure that the PCBU complies with its obligations under the HASWA. ${ }^{178}$ Moreover, the HASWA imposes liability not just on company directors, ${ }^{179}$ but on all "officers" of PCBUs. Unlike PCBUs, officers do not owe primary duties of care to workers and to other persons. ${ }^{180}$

$172 R v$ Burr, above $\mathrm{n} 24$, at [21]-[26].

173 At [30]-[31]. The director does not have to be discharging their duties as a director when they were involved in the company's breach of duty.

174 HASEA, above n 23, s 56.

175 McGall v Dominion Bookbinders Ltd DC Manukau CRI-2009-090-503893, 31 March 2010.

176 At [8] and [59].

177 At [56] and [60].

178 HASWA, above n 1, s 44

179 Section 18(a)(i).

180 Section 13(1)(b). 


\section{B The HASWA 2015}

\section{Who is an officer?}

The HASWA defines the term "officer" as a person occupying the position of director "by whatever name called", ${ }^{181}$ any partner in a partnership, ${ }^{182}$ any general partner in a limited partnership $^{183}$ or, for any other type of organisation, a person occupying a position comparable to that of a director. ${ }^{184}$ The term "officer" is not constrained by these definitions. The HASWA goes on to say that the officer can be any other person in a position to "exercise significant influence over the management of the PCBU". 185

It is not clear how far down the chain of command the due diligence duties extend. ${ }^{186}$ The definition of officer in the Corporations Act 2001 (Cth) has been adopted as the definition of officer under the Model Work Health and Safety Act 2011 (Australia). ${ }^{187}$ Section 9 of the Corporations Act 2001 (Cth) defines an officer as a director of a company, a partner in a partnership, an office holder of an unincorporated association, or "a person who makes, or participates in making, decisions that affect the whole, of a substantial part, of the business entity".

Receivers, administrators and liquidators are also caught under the definition of officer, as de facto directors. ${ }^{188}$ The definition of officer may also cover health and safety advisors, middle level managers, and general counsel as long as they are involved in making decisions that affect the whole or part of the business. ${ }^{189}$ The Australian jurisprudence suggests that the net of liability is therefore wider than under the previous law. Given that the New Zealand HASWA is based on the Australian Model Law for Occupational Health and Safety, it is highly likely that New Zealand courts will adopt a similar stance to Australian courts.

181 Section 18

182 Section 18(a)(ii).

183 Section 18(a)(iii)

184 Section $18(a)(i v)$

185 Section $13 \mathrm{~A}(\mathrm{~b})$.

186 First Report, above n 25, at [8.37].

187 Work Health and Safety Law 2011 (Cth), s 4; Second Report, above n 25, at Recommendation 88; and First Report, above n 25, at [8.33].

188 Sherriff and Tooma, above $\mathrm{n} 48$, at 32.

189 Simpson Grierson "Submission to Transport and Industrial Relations Committee, Health and Safety Reform Bill 2014" at 3. See also ASIC v Adler [2002] NSWSC 171, (2002) 41 ACSR 72 at [55]-[64]. 


\section{Duties of officers}

The following is a summary of what an officer needs to do to discharge their due diligence duties. ${ }^{190}$

- Officers need first-hand and up-to-date knowledge of the safety risks in their organisations to be able to interpret reports that are presented to them.

- Officers must keep a close eye on highly hazardous activities even when they involve a low chance of causing serious damage.

- Officers must ensure the business has adequate resources, including adequate staffing and infrastructure. ${ }^{191}$

- Officers must also have systems where information on hazard management in the business flows through to them. ${ }^{192}$

- Officers should also be the drivers of safety within the organisation. They are responsible for ensuring that the PCBU complies with its legal health and safety obligations. Safety systems should not be merely "on paper", but must actually work in practice. ${ }^{193}$

The duty to exercise due diligence does not mean that the officer has to do everything possible, but only to take reasonable care. ${ }^{194}$ The duty to take reasonable care implies that the officer will be judged based on what a reasonable officer should do in relation to what they knew, or ought to have known about the situation. 195

The liability of the officer is independent of the liability of the PCBU. It is possible for an officer to be charged with a failure to meet their obligations to exercise due diligence, even if the PCBU itself has not been charged with an offence. ${ }^{196}$

\section{Criminal liability of officers}

If an officer recklessly engages, without reasonable excuse, in conduct that exposes an individual to whom the PCBU owes a duty, to a risk of death or serious injury, then the officer can

190 HASWA, above n 1, s 44.

191 Sherriff and Tooma, above n 51, at 35 .

192 At 39.

193 At 41

194 Second Report, above n 35, at [23.167].

195 At [23.167].

196 HASWA, above n 1, s 50 
be made liable under s 47 of the HASWA. ${ }^{197}$ The penalties are a fine of up to $\$ 600,000$, a prison sentence of up to five years or both. Breaching the duty of due diligence is not part of the offence.

When an officer breaches their due diligence duties, for example, by not authorising the provision of enough resources to the PCBU to buy safety equipment, and as a consequence, an individual is exposed to a risk of death or serious injury, then the officer may be liable under s 48 of the HASWA and face a fine of up to $\$ 300,000$. An officer who simply breaches their due diligence duties may be liable for a breach of s 49 and may face a fine of up to $\$ 100,000$.

If $R v$ Burr and McGall $v$ Dominion Bookbinders Ltd were decided under the HASWA, ${ }^{198}$ the results would most likely be very similar. The directors would probably have fallen foul of s 48 of the HASWA. They had breached their due diligence duties by failing to ensure the company had proper processes to comply with its primary duty of care towards its workers and towards other persons. ${ }^{199}$ In $R v$ Burr, the director had failed to ensure that the safety procedures around tree felling were observed. In $M c G a l l$, the director had failed to ensure that the PCBU maintained the entrance gate was properly. The breaches of duty caused a death and a serious injury respectively. The directors would have been in breach of $\mathrm{s} 44$.

In addition, Mr Burr would also most likely also be liable under s 47 for recklessly engaging in conduct that caused the death of a worker as the facts of $R v$ Burr indicate that Mr Burr was reckless as to the risk of death or serious injury of his co-worker. ${ }^{200}$

\section{Will Deterrence Increase?}

The nature of the duty has changed. Under the previous law, the company officer would only be liable if they knew of the company's failure or participated in it. Now, the officer must take reasonable care to ensure that the PCBU is complying. ${ }^{201}$ They must also be proactive and take reasonable steps to ascertain what the PCBU must do to comply and ensure that compliance does occur. They cannot avoid liability by saying they did not know of the PCBU's failure. ${ }^{202}$ It is also not possible to delegate the duty to exercise due diligence as the duty is imposed qua office. ${ }^{203} \mathrm{~A}$

197 Section 47(2).

198 R v Burr, above n 24; and McGall v Dominion Bookbinders Ltd, above n 175.

199 HASWA, above n 1, s 44(4)(e).

$200 R$ v Burr, above n 24, at [36]-[37].

201 Second Report, above n 35, at [23.167].

202 Inspector Ken Kumar v David Aylmer Ritchie [2006] NSWIR Comm 384 per Haylen J.

203 Workcover Authority (NSW) v Akerman-Apache (Joint Venture) Pty Ltd [2006] NSWIR Comm 370. 
director can rely on other people's expertise when doing so is reasonable, ${ }^{204}$ but would still have to assure themselves personally that the health and safety duties of the PCBU have been discharged correctly. ${ }^{205}$

At first sight, it would appear that the imposition of a due diligence duty on more duty-holders will improve deterrence. However, there are three main reasons that deterrence will not increase significantly under the new law.

First, officers may hedge their bets against being caught. A survey of directors in Australia was carried out shortly after the Australian Model Workplace Health and Safety law was implemented. ${ }^{206}$ A third of directors surveyed did not change their behaviour after implementation. The survey did not explain why some directors did not change their behaviour. One can only speculate. On the one hand, perhaps the perceived threat of being caught is low. As explained above, there are not enough resources to adequately monitor all businesses. On the other hand, it may be the directors surveyed did not know how to comply; ${ }^{207}$ viewed compliance as an unnecessary burden; or thought compliance to be unachievable. Or perhaps the directors thought that what they were doing under the previous legal regime was sufficient to meet the requirements under the new regime.

Secondly, convictions against officers will be harder to secure. The procedural hurdles may be even harder to clear under the new law. WorkSafe has to prove, beyond all reasonable doubt, that due diligence was not exercised. ${ }^{208}$ Under the previous law, the defendant had the burden of proving that they had taken all practicable steps on a balance of probabilities.

Thirdly, the risk of a jail sentence remains virtually the same as it was under the old law. The threat of going to jail only applies when the officer breaches a duty and recklessly engages in conduct that is likely to cause death or serious injury. If an officer engages in such conduct, they could also be charged with manslaughter. The same situation existed under the old law. ${ }^{209}$

204 See Companies Act 1993, s 138.

205 Inspector Aldred v Herbert [2007] NSWIR Comm 170.

206 Cormak E Dunn "Survey Examines Impact of New Safety Laws on Directors" (2013) 65 Keeping Good Companies 165 .

207 The WorkSafe website does not proved specific guidance to officers on how they can comply. Nor are there enough inspectors going around helping officers understand their duties.

208 Karen Wheelwright "Understanding the Liability of Corporate Officers for Occupational Health and Safety Breaches in the Era of Harmonisation" (2012) 40 ABLR 410 at 422; and First Report, above n 25, at [8.24] and [8.31]. The prosecution will have the burden of proving that the officer did not exercise due diligence.

209 In $R v$ Burr, above n 24, the director was also charged with manslaughter. 
A breach of due diligence duties, without recklessness, that results in a death or serious injury, may now result in a higher fine for the officer. ${ }^{210} \mathrm{~A}$ breach of due diligence duties, without a risk of death or serious injury, may also result in a fine. ${ }^{211}$ Paying a fine is not something that white-collar criminals fear. ${ }^{212}$ What white-collar workers fear is their reputation being irreparably damaged by a prison sentence. Paying a fine is not viewed as leading to a loss of peer esteem, but getting a prison sentence is seen almost as a death knell for one's career. ${ }^{213}$

Thus, the deterrence for failing to comply with due diligence duties without recklessness, even when the breach results in death or serious injury, is minimal because paying a fine is not seen as a severe punishment by officers. Moreover, most officers of big organisations would be sophisticated enough to put their main assets into a trust, and thus shield themselves from the harshness of a big fine.

\section{THE REAL COST OF INCREASED DETERRENCE}

The design and implementation of the HASWA will not increase deterrence. Some suggestions to increase deterrence are presented here.

First, to increase the probability of being caught and punished, WorkSafe could be given more money to spend on inspections and on taking legal action. ${ }^{214}$ More funding means either increased taxes, or cutting funding somewhere else.

Secondly, by reducing the burden of proof, the number of successful prosecutions can be increased. WorkSafe's current strategy is to prosecute only when there is good evidence and it is in the public interest. Reducing the burden of proof is, however, untenable as it is a procedural safeguard which preserves the credibility of the legal system. Ultimately, citizens may stop believing in the law and stop following rules. ${ }^{215}$

However, one way to lower the standard of proof without reducing the credibility of the legal system would be to introduce a system of civil pecuniary penalties. ${ }^{216}$ As OHS offences are not

210 HASWA, above n 1, s 48 .

211 Section 49

212 William J Chamblis "Types of Deviance and the Effectiveness of Legal Sanctions" (1967) 3 Wis L Rev 703 at 709 .

213 At $709-710$.

214 Robinson and Darley, above n 13, at 993.

215 Neil Gunningham CEO and Supervisor Drivers: Review of Literature and Current Practice (National Occupational Health and Safety Commission, Australia, 1999) at 13.

216 For a survey of the use of civil pecuniary penalties in Australia see Michael Gillooly and Nii Lante WallaceBruce "Civil Penalties in Australian Legislation" (1994) 13 U Tas LR 269. 
perceived as serious offences and only as operating costs, ${ }^{217}$ the aim of increasing deterrence is not served. Civil penalties can be used legitimately when liability is strict and does not require proof of recklessness. And the civil penalties imposed could be much larger than the current fines, to increase deterrence. Civil pecuniary penalties would give WorkSafe another enforcement tool it could use for breaches that are not severe enough to warrant a criminal prosecution, but that nevertheless need to be punished and deterred. ${ }^{218}$

Thirdly, imposing harsher fines, even for small breaches could reduce accident rates overall. There is research that shows that a small breach of safety regulations leads to a tolerance of safety breaches within the organisation. ${ }^{219}$ Tolerance for small breaches builds up tolerance for bigger breaches by creating a poor safety culture. By not punishing small breaches harshly, the courts are not recognising the fact that small breaches usually lead to bigger breaches. But punishing small breaches severely may be seen as unjust. Moreover, the current rate of inspections would not allow for small breaches to be detected.

A final possibility is targeting other regulatory offences committed by the PCBU or its officers. In a study on controlling drug trafficking, David Kennedy found that targeting associated crime, such as illegal gun possession and other minor offences committed by the gangs, had a dramatic effect on reducing drug trafficking. ${ }^{220}$ In the HASWA context, the safety investigation following an accident could be coupled with a scrutiny of the PCBU's financial records. The fear of close scrutiny into the business affairs of the PCBU may be enough to ensure that PCBUs and their officers make the utmost effort to comply with safety regulation. However, targeting PCBUs and officers for other offences may be seen as a strong approach, resulting in resentment. It would also require increased resources which may not be available.

217 See MacCullum, Schofield and Reeve, above n 29.

218 See generally Ian Ayres and John Braithwaite Responsive Regulation: Transcending the Deregulation Debate (Oxford University Press, Oxford, 1992) at ch 2. The authors suggest that most of the enforcement activity of the regulator should be around education and persuasion. If the PCBU does not respond to education and persuasion, then the regulator escalates the enforcement measures to issue a warning. If the PCBU complies after the warning, the regulator can de-escalate their response and start using education and persuasion as tools to obtain compliance. However, if the PCBU still refuses to comply, then Ayres and Braithwaite suggest escalating the response to issuing civil pecuniary penalties, before escalating to criminal penalties.

219 Joan M Eakin and Ellen MacEachen "Health and the social relations at work: A study of the health-related experiences of employees in small workplaces" (1998) 20 Sociology of Health \& Illness 896.

220 See Kennedy, above n 11, at 4-7. 


\section{CONCLUSION}

In spite of increased penalties, a greater range of duty-holders and more resources being put into enforcement, deterrence is unlikely to increase significantly under the HASWA

While uncertainty in definitions may cause duty-holders to over-comply, the incentives to under-comply are weightier. The legal standards and requirements are mostly similar under the new law. Courts still have to consider the pecuniosity of the defendant when setting the fine amount. The amount of the fine will rarely exceed the amount the defendant would have had to spend to invest in complying safety measures. In spite of increased resources being put into enforcement, the likelihood of an inspection remains low.

The scope of the new powers of $H \& S$ representatives have been diluted to the extent that any increase in deterrence from these new powers is likely to be minimal. Making officers of PCBUs personally liable is good step towards increasing deterrence. However, the threat of detection and the possibility of a successful prosecution still remain low.

There is no doubt that criminal law does deter, but there is no evidence that deterrence will increase under the HASWA. Only a strong approach by WorkSafe, with the accompanying undesirable consequences, could increase deterrence significantly. 